\title{
AS CRÍTICAS DE DWORKIN LEVARAM A UMA SUPERAÇÃO DO LEGADO DE HART?
}

DWORKIN CRITICS LEAD TO HART LEGACY OVERCOMING?

Charles Nunes BAHIA ${ }^{1}$

ISSUE DOI: $10.21207 / 1983.4225 .715$

\section{RESUMO}

O embate jurídico-filosófico travado entre Hart e Dworkin conduz as rédeas do presente artigo. A intenção é suscitar o debate, indicando os pontos nevrálgicos da teoria hartiana de modo a confronta-los com as objeções e inovações trazidas pela teoria dworkiniana. Pretende-se com isso descobrir se as críticas de Dworkin levaram a uma superação do legado de Hart.

Palavras-chave: Hart. Dworkin. Regras. Princípios. Discricionariedade judicial.

\section{ABSTRACT}

The legal-philosophical clash established between Hart and Dworkin leads the reins of this article. The intention is to evoke debate, indicating the hot spots of hartian theory to confront them with the objections and innovations brought by dworkinian theory. The aim of this is find out if Dworkin's criticisms prompted an overcoming of Hart's legacy.

Keywords: Hart. Dworkin. Rules. Principles. Judicial discretion.

\footnotetext{
${ }^{1}$ Mestre em Teoria do Direito pela Pontifícia Universidade Católica de Minas Gerais (2016). Bacharel em direito pela Pontifícia Universidade Católica de Minas Gerais (2012). Graduando em Filosofia pela Universidade Federal de Minas Gerais. Realizou pesquisa (graduação-sanduíche) na Faculdade de Direito da Universidade do Porto (Portugal-2011/2012). http://lattes.cnpq.br/9995443491267552
} 


\section{INTRODUÇÃO}

As críticas de Dworkin ao modelo positivista desenvolvido por Hart ocupam importante espaço dentro da teoria do direito. Num cenário marcado por acusações e réplicas, a constatação hartiana a respeito da existência, na esfera jurídica, de uma inevitável discricionariedade judicial, ganha papel protagonista. Um embate se estabelece; pontos importantes ao desenvolvimento da acalorada discussão iniciada em fins de 1970 são trazidos ao debate; enquanto isso, uma série de questionamentos vão adquirindo contornos palpáveis.

A imersão nessa contenda revela o desafio que aqui se escolheu enfrentar. A intenção é percorrer os meandros que delineiam aprazível temática, iniciando-se por um apanhado geral da teoria de Hart. Logo em seguida, pretende-se trazer à discussão as principais acusações de Dworkin à teoria hartiana, dando-se ênfase especificamente a duas delas: a que fundamenta o equívoco do positivismo jurídico ao adotar uma visão do ordenamento jurídico como um conjunto exclusivo de regras legais, e a que reduz as correntes positivistas a teorias que pregam a discricionariedade judicial.

A construção principiológica de Dworkin será por fim revelada como promessa à satisfação das aporias do positivismo jurídico. Não obstante, ainda no transcorrer da rota hermenêutica oferecida por esse jusfilósofo estadunidense, será dada guarida à ideia do direito como integridade, permitindo-se uma abertura literária para duas importantes metáforas jurídicas voltadas à resolução dos dilemas que se estabelecem em torno da esfinge da coerência jurídica. Ao final, será então realizado um balanço dessas ideias; o objetivo é verificar se todas elas, em conjunto, conduzem a uma superação do positivismo jurídico de Hart pelo não positivismo jurídico de Dworkin.

\section{O LEGADO POSITIVISTA DE HART}

A fim de estabelecer uma avaliação acerca do pensamento de Dworkin, se faz necessária a compreensão de um dos principais objetos de 
sua crítica: o positivismo jurídico ${ }^{2}$. Em especial, a teoria positivista do direito de Hart. Destarte, a dissensão entre a concepção jusfilosófica do catedrático da Universidade de Oxford e a de seu sucessor partirá da compreensão dos elementos fundamentais da obra $O$ Conceito de Direito (HART, 2001).

Segundo Wayne Morrison, "a obra de H. L. A. Hart é amplamente reconhecida como o apogeu do positivismo jurídico" (MORRISON, 2012, p. 417). Neste sentido, O Conceito de Direito atua como o limiar de uma nova perspectiva do direito positivo, que integra a pretensão de estabelecer um estatuto científico, sistematizado e analítico do direito a partir da concepção pragmática da filosofia da linguagem ${ }^{3}$.

Para adequar-se à pretensão analítica do fenômeno jurídico, Hart parte de três questões fundamentais para a estrutura de sua teoria: "Como difere o direito de uma ordem baseada em ameaças e como se relaciona com essas? Como difere a obrigação jurídica da obrigação moral e como está relacionada com esta? O que são essas e em que medida é o direito uma questão de regras?" (HART, 2001, p. 18).

Apesar de herdeiro da tradição austiniana, Hart enxerga na teoria de John Austin os limites que ela oferece para compreender o direito como uma ordem normativa que se amolda às sociedades modernas. Em John Austin, o direito baseava-se essencialmente na relação entre o comando do soberano - detentor de Autoridade - que demandava um hábito geral de obediência, e os seus súditos que deveriam obedecê-lo. Hart critica fortemente a assimilação exclusiva das regras de direito como regras de obrigação. Para fundamentar sua crítica, o jusfilósofo inglês analisa comparativamente essa concepção com o moderno direito inglês:

Se compararmos a diversidade dos diferentes tipos de leis, que se encontram num sistema moderno como o direito inglês, com o modelo simples de ordens coercitivas construído no capítulo anterior, ocorre ao espírito uma grande quantidade de objecções. Por certo que nem todas as leis impõem às pessoas que façam ou não façam algo. Não será enganador classificar assim leis que conferem poderes aos particulares para outorgarem testamentos, celebrarem contratos ou casamentos, e leis que dão poderes aos funcionários, por

\footnotetext{
${ }^{2}$ Para fins didáticos, entender-se-á como positivismo jurídico todas aquelas vertentes teóricas responsáveis por pregar a separação entre direito e moral. Para mais informações, ver: ALEXY, Robert. Conceito e Validade do Direito. $2^{\mathrm{a}}$ ed. São Paulo: Martins Fontes, 2011a.

${ }^{3}$ Sobre a relação entre a filosofia da linguagem e a teoria jurídico-analítica de Hart, assim se manifesta Morrison (2012 p. 429): "A obra de maturidade do filósofo austríaco Wittgenstein exerceu forte influência sobre Hart [...] Wittgenstein passou a crer que, na verdade, a linguagem construía a realidade social. Portanto, era importante examinar o significado-em-uso das palavras".
} 
exemplo, a um juiz para julgar casos, a um ministro para fazer regulamentos ou a um conselho municipal para fazer posturas? (HART, 2001, p. 33)

Como solução para o problema detectado na teoria de John Austin, Hart propõe a estruturação do ordenamento jurídico a partir de uma dupla dimensão normativa, que consiste em regras primárias e regras secundárias. Dentro desse sistema de regras, as regras primárias podem ser compreendidas como aquelas que "são concebidas e referidas como impondo obrigações quando a procura geral de conformidade com elas é insistente e é grande a pressão social sobre os que dela se desviam ou ameaçam desviar-se" (HART, 2001, p. 96). Ou na leitura de Dworkin: "São aquelas que concedem direitos ou impõem obrigações aos membros da sociedade" (DWORKIN, 2002, p. 31). As regras secundárias, por sua vez, são aquelas que possibilitam a segurança e a adequação temporal e social do ordenamento jurídico em determinadas sociedades. Neste sentido, ao atentar sobre os problemas elencados por Hart ao tratar de uma ordem jurídica composta apenas por regras primárias, concluirá Morrison que:

\footnotetext{
Numa sociedade desenvolvida precisamos mais do que essa abordagem [de regras primárias] porque esta estrutura das regras não constituiria um sistema, faltar-lhe-ia coerência, e a razão estaria no fato de não haver modo algum de decidir os limites da regra e as relações entre as regras. Isso levaria: (i) ao problema da incerteza social quanto à posição relativa da regra e à força da obrigação imposta; (ii) significaria que não existem meios de modificar as regras em tal sociedade. [...] (iii) não haveria como determinar, finalmente, quando uma violação das regras teria ocorrido [...]. Isso levaria a uma ineficácia geral do sistema. (MORRISON, 2012, p. 439)
}

O trecho acima descrito aponta três objeções centrais à impossibilidade de que um sistema jurídico seja abalizado apenas por regras primárias: a incerteza, a estaticidade e a ineficácia. Para solucionar cada uma delas, proporá Hart três específicos tipos de regras secundárias. Assim, ao problema da incerteza, proporá o professor de Oxford uma regra de reconhecimento que "especificará algum aspecto ou aspectos cuja existência de uma dada regra é tomada como uma indicação afirmativa e concludente de que é uma regra do grupo que deve ser apoiado pela pressão social que ele exerce" (HART, 2001, p. 104). Ao problema da estaticidade, proporá ele uma regra de alteração, de modo a conferir "poder a um indivíduo ou a um corpo de indivíduos para introduzir novas regras primárias para a conduta da vida do grupo, ou de certa classe dentro dele, e para eliminar regras 
antigas" (HART, 2001, p. 105). Por fim, ao problema da ineficácia, proporá Hart uma regra de julgamento, que consiste numa série de determinações da forma mínima de julgamento, além de identificar os indivíduos que devem julgar e o processo a seguir (HART, 2001, p. 106).

Apesar das tentativas exaustivas de Hart em sistematizar a sua teoria do direito dentro de um protótipo de regras secundárias capazes de garantir a estabilidade do ordenamento jurídico, permanecia ali um limite frágil. Como se sabe, a sua teoria analítica interna-externa remete a uma tradição da filosofia da linguagem que comporta a imputação de sentidos à linguagem a partir de como esta é utilizada socialmente. Assim, sempre que conceitos linguísticos se apresentarem vagos e imprecisos, toda a construção teórica se fragiliza. Essa fragilidade, via de consequência, remete à prática dos tribunais, que mesmo pautada na objetividade da regra de julgamento, pode conduzir a "incertezas quanto à forma de comportamento exigido por elas" (HART, 2001, p. 139).

Nota-se, de tal modo, que determinadas regras podem ser dotadas de imprecisões linguísticas, sendo extremamente dependentes de atribuições de sentido (que podem ser diversos). Um exemplo é o comando segundo o qual animais são proibidos em determinado condomínio. A partir desse comando, é correto se questionar: a quais tipos de animais este comando se refere? Ou seja, uma pessoa poderia ter um peixe em sua residência? Esse comando seria válido para todo e qualquer animal ou somente para determinados tipos? A estas perguntas, responderá Hart com o conceito de textura aberta.

Sob a perspectiva hartiana, a textura aberta existente no ordenamento jurídico se mostrará como um problema todas as vezes que casos inéditos não encontrarem solução no direito vigente. Nesse cenário, a vagueza das regras existentes e a necessidade de se encontrar uma solução para o direito, exigirá do julgador a aplicação de seu poder discricionário como forma de supressão das lacunas normativas (BAHIA, 2013). Segundo o professor de Oxford:

A textura aberta do direito significa que há, na verdade, áreas de conduta em que muitas coisas devem ser deixadas para serem desenvolvidas pelos tribunais ou pelos funcionários, os quais determinam o equilíbrio, à luz das circunstâncias, entre interesses conflitantes que variam em peso, de caso para caso (HART, 2001, p. 148). 
Para esse jusfilósofo inglês, a textura aberta do direito acarreta dentro do ordenamento jurídico um inevitável poder discricionário que, exercido de forma equilibrada, se destinará a encontrar respostas legais aptas a regulamentar determinadas situações atípicas (BAHIA, 2013). Neste diapasão, é possível se afirmar que:

\footnotetext{
Em qualquer sistema jurídico, deixa-se em aberto um vasto e importante domínio para o exercício do poder discricionário pelos tribunais e por outros funcionários, ao tornarem precisos padrões que eram inicialmente vagos, ao resolverem as incertezas das leis ou ao desenvolverem e qualificarem as regras comunicadas, apenas de forma imperfeita, pelos precedentes dotados de autoridade (HART. 2001. p 149).
}

Na visão de Hart, seria inevitável que os juízes, ao exercerem a sua discricionariedade, não recaíssem no dilema das regras de textura aberta. Sempre que isto acontecesse, os tribunais apreciariam as regras jurídicas "como padrões a seguir na decisão, suficientemente determinados, apesar da sua textura aberta, para limitar o seu carácter discricionário, embora sem o excluir" (HART, 2001, p. 161).

O fato é que esse poder discricionário, reconhecido por Hart como inerente à atividade judicial, se torna alvo das críticas de Dworkin, que considerará essa discricionariedade uma arbitrariedade propiciada pela ideia de textura aberta do direito. Neste cenário, o jusfilósofo estadunidense parte da seguinte ofensiva direcionada ao pensamento hartiano: "Quero lançar um ataque geral contra o positivismo e usarei a versão de $\mathrm{H}$. L. A. Hart como alvo, quando um alvo específico se fizer necessário" (DWORKIN, 2002, p. 35).

Acredita-se, assim, que "ao tentar transformar o legado de Hart, Dworkin passa de uma estrutura positivista para uma estrutura hermenêutica ou interpretativa" (MORRISON, 2012, p. 528). Se dedicará ele, pois, a construir um sistema interpretativo do direito capaz de preencher as lacunas deixadas pelo positivismo jurídico. 
Visando contrapor a teoria positivista formulada por Hart, elaborará Dworkin uma teoria não positivista ${ }^{4}$ composta por duas partes: a primeira condizente em definir as condições necessárias e suficientes para que seja alcançada a verdade de uma proposição jurídica, e a segunda harmonizada no sentido de se conceituar o que direito deve ser, ou seja, a forma como as instituições jurídicas devem se comportar (DWORKIN, 2002).

Para o Dworkin, o positivismo jurídico funcionaria bem nos casos gerais (soft cases). A dificuldade, entretanto, se encontra no que ele chama de casos difíceis (hard cases), considerados aqueles que integram exatamente a zona de penumbra propiciada pela textura aberta do direito. Nesses casos, em que nada parece estar pré-definido, é que o jusfilósofo estadunidense passará a defender a coadunação dos valores de uma comunidade com os precedentes das decisões judiciais, de modo a dar origem aos princípios ${ }^{5}$. Estes, ao submergirem à realidade do ordenamento jurídico, passarão a servir como padrões de orientação aos juízes, reduzindo a discricionariedade judicial e, por consequência, restringindo o âmbito de abertura do direito. Sob a perspectiva dworkiniana, o maior equívoco das teorias positivistas seria a não aceitação de uma ordem principiológica capaz de colmatar aqueles espaços abertos muitas vezes não preenchidos pelas regras.

A importância dos princípios em um ornamento jurídico vem cuidadosamente fundamentada na obra Levando os direitos a sério (2002). No capítulo intitulado Modelo de Regas I, há visível abertura a um embasamento principiológico. Os princípios lá definidos são apresentados como padrões distintos das regras, isso porque sua observância obrigatória corresponde a uma exigência da moralidade. Veja:

A diferença entre princípios jurídicos e regras jurídicas é de natu-
reza lógica. Os dois conjuntos de padrões apontam para decisões
particulares acerca da obrigação jurídica em circunstâncias especí-
ficas, mas distinguem-se quanto a natureza da orientação que ofe-
recem. As regras são aplicáveis à maneira do tudo-ou-nada [...].
Mas não é assim que funcionam os princípios [...] Mesmo aqueles
que mais se assemelham a regras não apresentam consequências

\footnotetext{
${ }^{4}$ Para fins didáticos, entender-se-á como não positivistas todas aquelas teorias que defendam uma conexão necessária entre direito e moral. Para mais informações, ver: ALEXY, Robert. Conceito e Validade do Direito. $2^{\mathrm{a}}$ ed. São Paulo: Martins Fontes, 2011a.

${ }^{5}$ A definição dworkiniana de princípios pode ser extraída da seguinte passagem textual: "Denomino 'princípio' um padrão que deve ser observado, não por que vá promover ou assegurar uma situação econômica, política ou social considerada desejável, mas porque é uma exigência de justiça ou equidade ou alguma outra dimensão da moralidade" (DWORKIN, 2002, p. 36).
} 
jurídicas que se seguem automaticamente quando as condições são dadas (DWORKIN, 2002, p. 41).

Dentro desta diferenciação entre regras e princípios, Dworkin propõe ainda algumas diretrizes interpretativas para os juízes, segundo as quais: (a) deve-se encarar os princípios assim como se encaram as regras, possuindo o status de lei; (b) diferentemente das regras, cabe ao juiz decidir aplicar ou não os princípios, devendo buscar as razões de aplicabilidade destes além do que está definido nos textos legais ${ }^{6}$ (DWORKIN, 2002, p. 47-49).

Não restam dúvidas, pois, que o papel dos princípios no ordenamento jurídico seja colmatar aqueles espaços abertos impossíveis de serem alcançados pelas regras. No momento de abertura das decisões para os casos difíceis (hard cases), uma carga principiológica será colocada à disposição do magistrado de modo a orienta-lo para que ele não siga por caminhos arbitrários. Neste sentido, assevera Dworkin que:

[...] quando os juristas raciocinam ou debatem a respeito de direitos e obrigações jurídicos, particularmente naqueles casos difíceis nos quais nossos problemas com esses conceitos parecem mais agudos, eles recorrem a padrões que não funcionam como regras, mas operam diferentemente, como princípios, políticas e outros tipos de padrões. (DWORKIN, 2002, p. 35-36).

Ao desembaraçar-se daquele modelo positivista de regras, surge para o não positivista um espaço para a construção, mediante a adoção de princípios, de "um modelo mais fiel à complexidade e sofisticação de nossas próprias práticas" (DWORKIN, 2002, p. 72). Em resumo, reconhecendo a existência e a obrigatoriedade dos princípios não há espaço para a discricionariedade do julgador nos casos não regulados pela lei.

Dando continuidade às críticas direcionadas ao positivismo jurídico, discorrerá o capitulo intitulado Modelo de regras II - ainda na obra Levando os Direitos a Sério - sobre a questão da força vinculante das regras. A ideia é de que seja afastada a teoria da regra social de Hart, segundo a qual a exigibilidade das regras se mostra o resultado de um padrão da comunidade; isso porque aludida criação teórica hartiana mostrar-se-ia "incapaz de reconhecer a importante distinção entre dois tipos de moralidade

\footnotetext{
${ }^{6}$ De acordo com Morrison, Dworkin entende que: "A hermenêutica exige uma profunda sensibilidade diante das diferentes maneiras de arranjar-se no mundo vivido, invocando a análise histórica e a relatividade cultural - motivo pelo qual o "direito" se converte num termo vago que só tem sentido em situações concretas reconhecíveis pela análise histórica" (MORRISON, 2012, p. 525).
} 
social, que podemos chamar de moralidade concorrente e moralidade convencional" (DWORKIN, 2002, p. 85).

Para o jusfilósofo estadunidense, a teoria da regra social restaria falível sempre que a aplicação de determinada regra fosse considerada divergente, produzindo uma incerteza a respeito de qual seria a realidade social retratada pelo direito. Diante desse quadro, a suposta solução apresentada pelo positivismo jurídico consistiria tão somente em conferir discricionariedade ao julgador para que ele suprisse as lacunas do direito. Acolherse-ia, então, um pensamento circular moldado pela fracassada noção positivista de que o direito seja unicamente "um conjunto de regras especialmente selecionadas para reger a ordem pública" (DWORKIN, 2002, p. 30).

Sob a perspectiva dworkiniana, o positivismo jurídico passa a ser rotulado como uma "teoria segundo a qual os indivíduos só possuem direitos jurídicos na medida em que estes tenham sido criados por decisões políticas ou práticas sociais expressas" (DWORKIN, 2002, p. XV). Neste diapasão, a adoção da ideologia positivista, independentemente da versão acolhida, certamente conduziria à ilusória concepção de uma "pureza do direito". Por isso, ao parafrasear sua obra, sugere Dworkin que: "Se alguém levar a sério a ideia de que as regras jurídicas são, em certas de suas formas, 'completas' e 'integrais', poderá ser tentado a pensar que as leis 'completas' e 'integrais' são também independentes umas das outras" (DWORKIN, 2002, p. 120).

Os ataques teóricos intensificam-se ainda mais quando é trazida ao centro do debate a afirmação positivista de que "quando um caso não é coberto por uma regra clara, o juiz deve exercer seu poder discricionário para decidi-lo mediante a criação de um novo item de legislação" (DWORKIN, 2002, p. 49-50). Sob o prisma dworkiniano, essa assertiva ganhará contornos tão críticos, que a discricionariedade se transfigurará num conceito impreciso posto à disposição do julgador (Estado-juiz), situação na qual passará a existir um poder discricionário no sentido de que nenhuma autoridade superior poderá rever ou descartar a decisão (DWORKIN, 2002, p. 109).

Há de se salientar, todavia, que as críticas de Dworkin não se voltam para a existência do poder discricionário em si, mas tão somente à sua atuação num sentido forte. Deste modo, aquiesce o professor estadunidense com a possibilidade de que seja reconhecido um poder discricionário em sentido fraco, uma vez se mostrar impossível a erradicação de toda a 
discricionariedade da esfera judicial ${ }^{7}$. Nessa jornada considerada promissora, a figura dos princípios assume papel protagonista, buscando mitigar o problema teórico de integração do sistema jurídico através de padrões capazes de orientar o exercício da atuação dos magistrados diante daqueles casos não abrangidos por regras. Destarte, não havendo uma regra positivada aplicável ao caso concreto, deverá o julgador lançar mão de recursos oferecidos pelo próprio sistema (princípios explícitos ou implícitos), afastando-se por completo o mero arbítrio.

O fato é que mesmo diante desse arquétipo teórico lançado por Dworkin, poder-se-ia questionar o porquê dessa função integradora exercida pelos princípios não poder ser também realizada por regras. Este questionamento, no entanto, se mostra facilmente passível de ser desmantelado, bastando que se tome conhecimento da afirmação de que "regras são aplicáveis à maneira do tudo-ou-nada" (DWORKIN, 2002, p. 39), o que equivale a dizer que uma regra somente pode ser considerada válida ou inválida, inexistindo uma terceira opção. Logo;

Se duas regras entram em conflito, uma delas não pode ser válida. A decisão de saber qual delas é válida e qual deve ser abandonada ou reformulada, deve ser tomada recorrendo-se a considerações que estão além das próprias regras. Um sistema jurídico pode regular esses conflitos através de outras regras, que dão precedência à regra promulgada pela autoridade de grau superior, à regra promulgada mais recentemente, à regra mais específica ou outra coisa desse gênero. (DWORKIN, 2002, p. 43).

Deve-se ter em conta que o corolário de um sistema jurídico regulado por regras e princípios é exatamente a ideia de um conjunto coe-

\footnotetext{
${ }^{7}$ Dworkin chama a atenção para a existência de dois tipos de poder discricionário, sendo um em sentido fraco e outro em sentido forte. Em relação ao primeiro tipo (sentido fraco), o filósofo o desmembra em dois subtipos, empregando-se o primeiro subtipo (sentido fraco-fraco) "apenas para dizer que, por alguma razão, os padrões que uma autoridade pública deve aplicar não podem ser aplicados mecanicamente, mas exigem o uso da capacidade de julgar" (DWORKIN, 2002, p. 51). Quanto ao segundo subtipo (sentido fraco-forte), este seria usado "apenas para dizer que algum funcionário público tem a autoridade para tomar uma decisão em última instância e que esta não pode ser revista e cancelada por nenhum outro funcionário" (DWORKIN, 2002, p. 51). Entretanto, no que tange ao segundo tipo (sentido forte), seria este empregado para dizer que, em certos assuntos, por não haver uma ordem dirigindo a decisão a ser tomada, não haveria limitações advindas de qualquer padrão proveniente de uma autoridade, possibilitando-se uma grande margem de escolha. Em suas críticas, Dworkin afirma que Hart teria utilizado a discricionariedade em seu sentido forte, por defender a prerrogativa do magistrado em emitir quaisquer juízos de valores para resolver o caso. Sob esse aspecto, os padrões de escolha de um magistrado, jamais estariam limitados por um direito preexistente. Para mais informações ver: DWORKIN, Ronald. Levando os direitos a sério. São Paulo: Martins Fontes, 2002.
} 
rente e harmônico compreendido em sua inteireza, o que significa a compreensão de um ordenamento jurídico isento de contradições jurisprudenciais. Esta ideia, no entanto, se mostra presente apenas de forma primitiva na obra Levando os direitos a sério. Em escritos posteriores, Dworkin trabalhará mais a fundo a questão, abordando a temática do direito como integridade ${ }^{8}$.

Na obra O Império do Direito (DWORKIN, 2003), o problema da abertura à discricionariedade judicial se depara com novas formas de combate; para além da base principiológica outrora proposta, passam a existir mecanismos interpretativos capazes de mitigar o exercício desmedido do poder discricionário. A interpretação assume o centro do debate; chega ela amparada por duas metáforas literárias. Daí em diante, a tão almejada integridade do ordenamento jurídico ${ }^{9}$ será fundamentada no romance em cadeia e no juiz Hércules ${ }^{10}$.

Para Dworkin, a interpretação do direito deveria ocorrer da mesma forma que se dá um romance em cadeia. Assim, se no romance, à medida que os capítulos vão sendo escritos, os romancistas subsequentes leem e interpretam esses capítulos de modo a dar continuidade à estória sem que ela se quebre ou perca o sentido, no universo jurídico, o caminho deverá ser semelhante, devendo os juízes prestarem atenção em tudo aquilo antes interpretado e julgado, de modo a impedir que sejam abertas as margens para equívocos e contradições que conduzam a uma ruptura do direito consigo próprio. Na visão do jusfilósofo estadunidense: “A complexidade dessa tarefa reproduz a complexidade de decidir um caso difícil de direito como integridade" (DWORKIN, 2003, p. 276).

A ideia é de que exista um nível aceitável de coerência no ordenamento jurídico. Todavia, para alcançar este fim, os mesmos juízes que se dispuseram a interpretar o direito observando a metáfora do romance em

\footnotetext{
${ }^{8} \mathrm{O}$ direito como integridade é uma construção dworkiniana que se contrapõe ao convencionalismo. As bases sobre as quais ela se funda tomam como pressuposto a necessidade de que os juízes justifiquem suas decisões conforme as interpretações passadas já realizadas. O mais importante em uma teoria desse tipo é que seja dada a devida atenção aos questionamentos, às perguntas sobre os reais motivos que teriam levado outros aplicadores anteriormente a proferir decisões sobre casos semelhantes. Para mais informações, ver: DWORKIN, Ronald. O Império do Direito. São Paulo: Martins Fontes, 2003.

${ }^{9}$ A relevância dessa integridade no ordenamento jurídico deve ser considerada observando-se "o princípio da stare decisis [decisão de acordo com os casos julgados]" (DWORKIN, 2002, p. 122), que é essencial para o sistema Common Law.

${ }^{10}$ A metáfora do juiz Hércules já se mostra presente na obra Levando os Direitos a Sério (DWORKIN, 2002). Todavia, a intensificação dessa alusão metafórica ocorre de fato na obra $O$ Império do Direito (DWORKIN, 2003). Salienta-se, inclusive, ser a ideia do direito como integridade uma derivação do modo de agir de Hércules diante dos casos difíceis (hard cases).
} 
cadeia deverão tentar se aproximar o máximo possível da figura romântica do juiz Hércules, um ser onisciente, capaz de transpor as barreiras impostas pelas situações mais complexas. Assim, "havendo conflito entre princípios, a ser resolvido na dimensão do peso, o juiz Hércules realizaria uma apreciação moral da questão conforme o direito, de forma que seja tomada a melhor decisão possível para aplicação da lei ao caso" (BAHIA, 2013). Neste sentido, a possibilidade de um erro decisório seria mínima, já que Hércules realiza uma interpretação construtivista, levando em consideração as tradições morais daquela comunidade dentro da qual ele atua (DWORKIN, 2002, p. 196).

Ao se espelhar em Hércules, o magistrado estará prestando inegável contributo à reconstrução do direito como integridade. $\mathrm{O}$ resultado profícuo de tudo isso será o alcance da única resposta correta, considerada o resultado da melhor justificativa que se possa dar para o conjunto de proposições de direito tidas como estabelecidas (DWORKIN, 2005, p. 211).

A única resposta correta é, portanto, a consequência esperada por Dworkin. Desde as críticas tecidas ao positivismo jurídico, perpassando pelo modelo de princípios, até chegar à ideia do direito como integridade, muitas inovações foram sendo lançadas no campo da teoria do direito. Todas elas, em conjunto, acabaram por desencadear o protótipo de comunidade interpretativa que, segundo Morrison, pode assim ser resumido:

\begin{abstract}
A prática interpretativa não é independente, mas sim parte de uma tradição ou comunidade, e tem um pendor reformista. Dworkin apresenta três etapas: (i) a pré-interpretativa, em que se identifica a prática; (ii) a interpretativa, em que a pessoa que interpreta justifica, em termos gerais, por que vale a pena dar continuidade à prática, e (iii) a pós-interpretativa caracterizada pela reforma, em que a prática se ajusta conforme as exigências de justificação estabelecidas na etapa interpretativa. Isso é reflexivo ou autorreferencial no sentido de que a justificação provém (de aspectos) da prática e, por sua vez, informa e configura o desenvolvimento dessa prática. Dessa forma, Dworkin caracteriza o direito como uma prática interpretativa fundada num consenso geral quanto à natureza do direito. (MORRISON, 2012, p. 528)
\end{abstract}

No encalço de Wayne Morrison, a proposta dworkiniana se torna mais clara. A crítica ao positivismo jurídico, em especial à teoria positivista de Hart, parece no final ir além da zona de arrebentação do poder discricionário. A distinção entre regras e princípios se revela como parte de um 
percurso que abrange a busca de uma solução racional aos litígios envolvendo interpretação; o direito como objeto independente se transforma, enfim, em consenso interpretativo (MORRISON, 2012, p. 531).

\section{UMA SUPERAÇÃO DO LEGADO DE HART?}

O modelo positivista de Hart é bastante claro e coeso, embora preso a suas próprias limitações. A intenção do professor de Oxford foi a de desenvolver um protótipo de direito capaz de se adequar às nuances das sociedades complexas. Tinha ele consciência das dificuldades em se definir um conceito lógico de direito e, por esse motivo, preferiu conceber a atividade jurídica como um conjunto de práticas sociais (COTTERRELL, 1989, p. 92). Da textura aberta da linguagem ${ }^{11}$ (WAISMANN, 1978), extraiu-se a textura aberta do direito e, daí em diante, tornou-se mais fácil entender as razões pelas quais se mostraria impossível vislumbrar o ordenamento jurídico como um conjunto de regras primárias capazes de abarcar todos os casos existentes. As lacunas deixadas em aberto pelo legislador se tornavam uma realidade irrefutável; enquanto isso, um poder discricionário surgia como mecanismo hábil para se conceder respostas plausíveis aos impasses judiciais.

Ainda hoje a teoria de Hart permanece como importante modelo a ser seguido. Críticas, todavia, persistem; a maioria delas fundadas em argumentos puramente dworkinianos. Não se deve esquecer que o papel de Dworkin em um cenário de tentativas de superação do positivismo jurídico se mostrou de grande valia. Os ataques teoréticos tecidos por esse autor estadunidense em relação à filosofia jurídica hartiana foram vários; daí a importância de estuda-los de maneira cuidadosa.

Após percorrer o espaço de compreensão do modelo conceitual ofertado pela teoria de Dworkin, surgem os seguintes questionamentos: seria possível afirmar ter havido uma superação do legado hartiano? As críticas dworkinianas se mostraram fortes o suficiente a ponto de inutilizar argumentos em defesa do positivismo jurídico analítico? Para responder à

\footnotetext{
${ }^{11}$ Depois de realizar uma releitura do conceito de textura aberta da linguagem apresentado por Waismann, Noel Struchiner assim o definirá: "Por textura aberta da linguagem, Waismann pretende dizer que os nossos conceitos empíricos não estão delimitados, de forma a priori, em todas as direções possíveis. Os conceitos empíricos não apresentam uma definição exaustiva, ou seja, nenhum conceito se encontra delimitado de forma que não surjam espaços para dúvida sobre o seu significado" (STRUCHINER, 2001, p. 11).
} 
primeira pergunta, será imperioso conceder antes respostas à segunda pergunta.

Pois bem. Ao seguir a argumentação dworkiniana, será possível perceber que o alvo de suas críticas remete à questão da discricionariedade judicial levantada por Hart na obra $O$ Conceito de Direito. Para o jusfilósofo estadunidense, o grande problema do positivismo jurídico estaria em permitir que os magistrados exercessem um poder discricionário desmedido sempre que se deparassem com casos desprovidos de regulamentação. Isto se daria justamente porque sob a ótica positivista, o ordenamento jurídico redundaria fadado a um conjunto hermético de regras, desprezandose a existência de princípios.

A objeção acima exposta pode, todavia, ser contra-atacada afirmando ser falácia o argumento de que a teoria jurídico-analítica de Hart não admite a existência de princípios. Basta apenas que seja realizada uma leitura adequada da teoria hartiana para se perceber que o jusfilósofo inglês, ao tratar das regras de textura aberta, estaria na verdade realizando uma alusão implícita ao que Dworkin considera como princípios ${ }^{12}$. Logo, as regras de Hart englobariam tanto aquilo que Dworkin chama de regras quanto aquilo que ele chama de princípios, com a diferença, de resto não pouco significativa, que para aquele elas estão separadas da moral enquanto pare este não (TRIVISONNO, 2006, p. 48).

Logo, se a teoria de Hart admite uma base principiológica, permitindo que padrões diferentes de regras ${ }^{13}$ passem a integrar a esfera jurídica de modo a dar cabo aos problemas ainda não regulamentados pelo direito, por terra deverá cair a afirmação dworkiniana de que o poder discricionário exaltado na obra $O$ Conceito de Direito seja uma manifestação irracional de desmedida arbitrariedade judicial. O próprio Hart, em pósescrito, rebate essa acusação afirmando que:

É importante que os poderes de criação que eu atribuo aos juízes, para resolverem os casos parcialmente deixados por regular pelo direito, sejam diferentes dos de um órgão legislativo: não só os poderes do juiz são objectos de muito constrangimento que estreitam

\footnotetext{
${ }^{12}$ Esses princípios, se vislumbrados da forma como explicitados por Dworkin, equiparar-se-ão também à ideia bobbiana de norma geral inclusiva. Sob a perspectiva do italiano Norberto Bobbio, todas as vezes que não seja encontrada uma solução na lei para determinado caso, deverá o impasse ser solucionado com o auxílio de outras fontes do direito (costumes, analogia, etc.), fontes estas indicadas justamente pela norma geral inclusiva. Para mais informações, ver: BOBBIO, Norberto. Teoria do ordenamento jurídico. 6 ed. Brasília: UnB, 1995, p. 135.

${ }^{13}$ O significado da palavra "regra" deve aqui ser entendido no sentido dworkiniano, ou seja, como critério de aplicação do direito de modo "tudo ou nada".
} 
a sua escolha, de que um órgão legislativo pode estar consideravelmente liberto, mas, uma vez que os poderes dos juízes são exercidos apenas para ele se libertar de casos concretos que urge resolver, ele não pode usá-los para introduzir reformas de larga escala ou novos códigos. Por isso, os seus poderes são intersticiais, e também estão sujeitos a muitos constrangimentos substantivos. Apesar disso, haverá pontos em que o direito existente não consegue ditar qualquer decisão que seja correcta e, para decidir os casos em que tal ocorra, o juiz deve exercer os seus poderes de criação do direito. Mas não deve fazer isso de forma arbitraria: isto é, ele deve sempre ter certas razões gerais para justificar a sua decisão é deve agir como um legislador consciencioso agiria, decidindo de acordo com suas próprias crenças e valores. Mas se ele satisfizer estas condições, tem o direito de observar padrões e razões para a decisão, que não são ditadas pelo direito e podem diferir dos seguidos por outros juízes confrontados com casos difíceis semelhantes (HART, 2001, p. 336).

\section{No mesmo sentido, ainda em defesa Hart, assim se manifesta Ro- bert Yanal:}

Tenho a certeza, nunca tive a intenção de que os juízes tivessem um poder discricionário em sentido forte. É claro, nem que tenham eles apenas poder discricionário em sentido fraco. Na verdade, eu me pergunto se há algum poder discricionário em sentido fraco. Se eu disser a você, 'Arquive esses memorandos'. Como? Use seu poder discricionário, estou apenas dizendo, ou eu indico que você faça isso? Acredito que Hart iria conceder um poder discricionário em sentido fraco aos juízes: o de que os juízes não podem decidir um caso difícil de qualquer maneira (por isso eles não têm poder discricionário em sentido forte), mas dentro dos parâmetros dos princípios e normas pertinentes ao caso, há uma livre escolha legal (YANAL, 1985, p. 394-395, tradução livre) ${ }^{14}$.

\section{Acredita-se aqui, haver uma grande parcela de razão nesses con- tra-argumentos. Parece mesmo soar como absurdo a afirmação de que a teoria do professor inglês esteja alicerçada em uma discricionariedade forte. Tecer alegações como esta, significa reduzir a teoria analítica harti- ana a um positivismo legalista há muito tempo superado ${ }^{15}$. Se de fato fosse}

\footnotetext{
${ }^{14}$ No original: "I am quite sure, never intended that judges have a strong sense of discretion. Of course, neither did he intend them to have only discretion in the weak sense either. In fact, I wonder if there is any weak sense of discretion. If I say to you, file these memos. How? Use your discretion, am I only saying, I nominate you to do it? I believe that Hart would grant a moderate sense of discretion to judges: that judges cannot decide a hard case just any way (hence they do not have strong discretion), but within the parameters of the rules principles relevant to the case there is a legally unconstrained choice". ${ }^{15} \mathrm{O}$ positivismo legalista tem seu apogeu a partir do início do século XIX. Naquele tempo, a ideia de um ordenamento jurídico completo, desprovido de lacunas e antinomias, dava força ao surgimento de importantes correntes jurídicas, como por exemplo, a Escola da Exegese. A virada para o século XX, entretanto, já vem trazendo consigo a superação dessa forma de se pensar o direito, que paulatinamente
} 
possível defender, de forma incondicional, que a discrionariedade judicial na teoria de Hart esteja limitada por padrões principiológicos, todas as críticas de Dworkin flutuariam no ar. Isto somente não ocorre porque sobra uma constatação capaz de diferenciar a abordagem crítica de ambas as teorias. Percebe-se, então, que se de um lado Hart utiliza-se dos princípios para justificar o poder discricionário, de outro Dworkin faz desses mesmos princípios um meio de superação dessa discricionariedade atestada na teoria hartiana (TRIVISONNO, 2006, p. 49).

Essa tentativa de superação da discricionariedade judicial através dos princípios acaba conduzindo Dworkin a espaços que extrapolam os contornos ofertados pela teoria de Hart. Para além das críticas ao legado hartiano, uma teoria construtivista foi desenvolvida; dentro dela foi recriado um protótipo hermenêutico-interpretativo. Por meio da metáfora, o juiz Hércules surgia como ideia reguladora; pelas vestes da mesma figura de linguagem, um romance em cadeia trazia a promessa da coerência. Seguir esses passos significava dar um salto em direção à superação do positivismo, o mesmo positivismo que delineia a teoria de Hart. Retoma-se, então, a primeira das duas perguntas anteriormente feitas, agora reformulada: o direito como integridade conseguiu sobrepujar o legado hartiano?

Do alto de uma condição epistêmica ideal, o juiz Hércules insistirá em servir de paradigma de justeza ao direito. Sinônimo da racionalidade jurídica, será ele incapaz de se curvar à corrupção ou dar atenção a alegações subjetivas. Enquanto mítico magistrado, se pautará na equidade; terá na justiça o alicerce jurídico para a coerência; terá na coerência a chave mestra à construção de uma história institucional. Ao final, um romance em cadeia regulará o modo de tomada das decisões. Tudo nesta ordem, obedecendo-se a um processo racional monológico que condiciona a moralidade aos ditames morais de Hércules.

O que se vê, no fïm das contas, é um acesso privilegiado à justiça, acesso este concedido apenas ao super-juiz. Ficam de fora desse cenário todos os interlocutores da relação jurisdicional. O fato da razão ser monológica, ou seja, pautada apenas no sujeito, não somente afasta a possibilidade do discurso como também acaba por canalizar em Hércules a onisciência sobre todos os fatos que integram o universo jurídico. Inexiste ali

vai dando lugar àquilo que hoje se denomina positivismo jurídico analítico. Dentro desta corrente, destacam-se expoentes como Bentham, Austin, Kelsen e Hart. Para mais informações, ver: BOBBIO, Norberto. O Positivismo Jurídico - lições de filosofia do direito. Tradução de Márcio Pugliese. São Paulo: Ícone, 1995. 
uma razão dialógica, capaz de se voltar ao discurso como mecanismo necessário à obtenção da verdade. A verossimilhança dos fatos se perde em meio a uma concepção opaca da justiça, fornecida de forma idealizada e unilateral. Peca-se por não haver um agir comunicativo, entendido na perspectiva habermasiana como a possibilidade de todos os atores (não só o juiz) "harmonizarem internamente seus planos de ação e de só perseguir suas respectivas metas sob a condição de um acordo existente ou a se negociar sobre a situação e as consequências esperadas" (HABERMAS, 1989, p. 164-165).

Essa razão comunicativa se torna ainda mais comprometida quando a figura do romance em cadeia surge para limitar possíveis críticas aos julgamentos pautados em Hércules. Sob a ótica dessa história institucional, os costumes e as práticas sociais deixam de ser objeto do discurso, pois inseridas "corretamente" numa leitura anterior promovida por outros autores. Quer-se com isso chegar à única resposta correta ${ }^{16}$. Utopia ou possibilidade? Ilusão ou verdade? Uma possível superação do legado de Hart permanece condicionada a estes questionamentos.

\section{$5 \quad$ CONCLUSÃO}

O desenvolvimento de uma teoria do direito capaz de se amoldar aos anseios de uma sociedade complexa já é, por si só, um grande legado. No entanto, nenhum valor teria tido essa mesma teoria se sobre ela não se despejassem críticas capazes de questiona-la. Há de se convir que seja justamente a discussão o elemento favorável à compressão dos meandros teóricos desenvolvidos por determinado autor durante certo período de tempo. Sem os ataques dworkinianos, as alegações hartianas não ganhariam a força que ganharam. Dworkin cumpriu muito bem esse papel; colocou em evidência os pontos fracos da proposta teórica de Hart e foi devidamente reconhecimento pelo feito. Restou saber, no entanto, se as acusações tecidas levaram ou a uma superação do legado hartiano.

\footnotetext{
${ }^{16}$ Em posição dissonante daquela defendida por Dworkin, situa-se Alexy, afirmando ser impraticável a ideia de que o procedimento discursivo seja sempre capaz de produzir uma única resposta correta. Esta, por ser complicada ou até impossível de ser alcançada, deve ser vislumbrada tão somente como uma ideia reguladora do processo discursivo. Sob o ponto de vista alexyniano, portanto, a única resposta correta somente seria obtida em condições ideais do discurso, de modo aproximado. Para mais informações ver: ALEXY, Robert. Teoria da argumentação jurídica: a teoria do discurso racional como teoria da fundamentação jurídica. 3 ed. Trad. Zilda Hutchinson Schild Silva. Rio de Janeiro: Forense, $2011 b$.
} 
Neste artigo, buscou-se trabalhar os principais pontos de atrito resultantes desse embate jurídico-filosófico. Ao se partir de uma análise sucinta do que foi exposto, percebeu-se que: 1 - A crítica de Dworkin condizente em afirmar que a teoria de Hart seja desprovida de princípios parecia fracassar diante da constatação de uma base principiológica existente na teoria hartiana sob a roupagem de regras de textura aberta; 2 - A alegação dworkiniana de que a teoria de Hart se utiliza de um poder discricionário desmedido, também parecia cair por terra diante das evidências da preferência do jusfilósofo inglês por uma discrionariedade moderada; 3 O ponto de dissidência entre ambos os teóricos parecia residir no fato de que enquanto para Hart os princípios estariam sendo utilizados como mecanismos de constatação do poder discricionário, para Dworkin os mesmos princípios estariam sendo avocados como meio de redução dessa discrionariedade.

Em relação a teoria do direito como integridade, foi desenvolvida uma argumentação visando colocar em destaque o problema daquela razão monológica que serve de alicerce ao Juiz Hércules. Nesse mesmo contexto, foram apresentados os problemas de se aceitar uma racionalidade condicionada à moralidade de um único sujeito. Deu-se também ênfase à distorção da verdade e à impossibilidade de existência do discurso nessas condições ideais. Por fim, perpassou-se sobre a problemática do romance em cadeia, fazendo evidenciar os problemas que enfrenta essa teoria metafórica diante da supressão de pontos de vista críticos. Como possível solução a tudo isso, ponderou-se a favor de uma razão dialógica.

Não houveram conclusões precisas, científicas ou categóricas. A pergunta que intitula o artigo foi apenas um convite ao pensar. Sabe-se que seja impossível responder com exatidão se houve ou não uma superação do legado hartiano. O que se quis foi fomentar ainda mais a dúvida. Fica a critério do leitor engajar-se ou não nessa empreitada árdua em busca de respostas.

\section{REFERÊNCIAS}

ALEXY, Robert. Conceito e Validade do Direito. $2^{\text {a }}$ ed. São Paulo: Martins Fontes, 2011 a.

ALEXY, Robert. Teoria da argumentação jurídica: a teoria do discurso racional como teoria da fundamentação jurídica. 3 ed. Trad. Zilda Hutchinson Schild Silva. Rio de Janeiro: Forense, 2011b. 
BAHIA, Charles Nunes. A discricionariedade judicial à luz das teorias de Hart e Dworkin. In: Âmbito Jurídico, Rio Grande, XVI, n. 118, nov 2013.

BOBBIO, Norberto. O Positivismo Jurídico - lições de filosofia do direito. Tradução de Márcio Pugliese. São Paulo: Ícone, 1995.

BOBBIO, Norberto. Teoria do ordenamento jurídico. 6 ed. Brasília: UnB, 1995, p. 135.

COTTERRELL, Roger. The politics of jurisprudence. A critical introduction to legal philosophy. Londres e Edimburgo: Butterworth, 1989

DWORKIN, Ronald. Levando os Direitos a Sério. São Paulo: Martins Fontes, 2002.

DWORKIN, Ronald. O império do direito. São Paulo: Martins Fontes, 2003.

DWORKIN, Ronald. Uma questão de princípio. São Paulo: Martins Fontes, 2005.

HABERMAS, Jürgen. Consciência moral e agir comunicativo. Tradução de Guido A. de Almeida. Rio de Janeiro: Tempo Brasileiro, 1989.

HART, H. L. A. O Conceito de Direito. Pós-escrito editado por Penélope A. Bulloch e Joseph Raz. Tradução de A. Ribeiro Mendes. $3^{\mathrm{a}}$ ed. Lisboa: Calouste Gulbenkian, 2001.

MORRISON, Wayne. Filosofia do direito: dos gregos ao pós-modernismo. São Paulo: Martins Fontes, 2006.

STRUCHINER, Noel. Uma análise da textura aberta da linguagem e sua aplicação ao direito. 2001. 102 f. Dissertação (Mestrado) - Pontifícia Universidade Católica do Rio de Janeiro (PUC-RJ), Programa de Pós-graduação em filosofia, Rio de Janeiro, 2001.

TRIVISONNO, Alexandre Travessoni Gomes. Kant e o pós-positivismo no direito. Revista da Faculdade de Direito. Universidade Federal de Minas Gerais, v. 48, p. 39-66, 2006.

WAISMANN, Friedrich. Verifiability. In: FLEW, Antony (coord.). Logic and language. Oxford: Balckwell, 1978, p. 177-144.

YANAL, Robert J. Hart, Dworkin, Judges, and New Law. In: The Monist, v. 68, n. 3. Illinois: The Hegeler Institute, 1985, p. 388-402. 